w Katowicach; wkład w rozwój Poradni Wychowawczo-Leczniczej w Krakowie; prace w Naukowym Towarzystwie Pedagogicznym; współprace naukowa z Towarzystwem Uniwersytetu Robotniczego im. A. Mickiewicza w Krakowie oraz pelnienie funkcji rektora Wyższej Szkoły Pedagogicznej w Krakowie. Autor szeroko uwzględnia wkład uczonego w rozwój i organizację tych placówek.

Uwzględniając wkład Mysłakowskiego w rozwój nauk pedagogicznych przedstawia kierunki zainteresowań naukowych uczonego. Autor ukazuje jego poglądy na pedagogikę jako nauke; poglądy pedeutologiczne; koncepcję i uwarunkowania procesu wychowania, stosunek Mysłakowskiego do funkcjonujących ideałów wychowania oraz stosunek uczonego do roli podręcznika w procesie dydaktycznym.

Szeroko została omówiona społeczna i polityczna postawa Z. Mysłakowskiego.

Ewa Trojanowska

\title{
Iwonna Michalska, Czasopisma Związku Nauczycielstwa Polskiego dla dzieci w okresie Drugiej Rzeczypospolitej, Wydawnictwo Uniwersytetu Lódzkiego, Lódź 1994, ss. 193.
}

$\mathrm{Na}$ tle zmieniających się warunków polityczno-społecznych i oświatowych wraz $z$ uwzględnieniem tendencji $w$ pedagogice, psychologii $i$ literaturze w Polsce $w$ okresie międzywojnia autorka dokonuje analizy działalności ZNP w dziedzinie wydawnictw dla dzieci. Książka poświęcona jest pięciu czasopismom dla młodych czytelników: „Płomykowi”, „Płomyczkowi”, „Małemu Płomyczkowi”, „Szkolnej Gazetce Ściennej” oraz „Młodemu Zawodowcowi". Znajdujemy tu informacje na temat dziejów poszczególnych wydawnictw z podkreśleniem czynników mających wpływ na ich zróżnicowany charakter. Autorka nie pominęła zagadnienia czytelników, charakteryzując ich środowisko społeczne, miejsce zamieszkania oraz omawiając formy upowszechniania $i$ udostępniania pism wśród dzieci i młodzieży.

Naîwięcej miejsca poświęcono kierunkom oddziaływań wychowawczych wyżej wymienionych czasopism. Autorka prezentuje ich rolę w kształtowaniu religijnej, moralnej, społeczno-obywatelskiej, patriotycznej, intelektualnej, estetycznej i fizycznej sylwetki dziecka. W zakończeniu rozprawy ukazano recepcje związkowych czasopism oraz dokonano próby ich oceny.

(E. T.)

\section{Krzysztof Stopka, Szkoly katedralne metropolï gnieźnieńskiej w średniowieczu. Studia nad ksztaltowaniem kleru polskiego w wiekach średnich, PAU, Rozprawy Wydziału Historyczno-Filozoficznego, t. 76, Kraków 1994, ss. 274.}

Szkoły katedralne należą do najstarszych szkół, ich geneza sięga czasów schyłku starożytności. Na ziemiach polskich powstały one zapewne już w XI wieku.

Podjęte przez autora zagadnienie szkót katedralnych $w$ okresie średniowiecza było już w przeszłości w kręgu zainteresowań badaczy (A. Karbowiak, S. Chodyński, J. Skoczek; konkretnie o szkołach tego typu w metropolii gnieźnieńskiej pisali: E. Meyer, M. Rechowicz,
I. Pawlak). Jednakże żadna z prac nie stanowi całościowego opracowania zagadnienia $w$ odniesieniu do terenów ówczesnej Polski, czy nawet poszczególnych jej części.

Badania nad szkolnictwem niższym nie są łatwe, ze względu na ograniczony zasób źródeł jakie instytucje te po sobie pozostawiły. Stąd tak interesująca jest praca K. Stopki.

Praca obejmuje obszar arcybiskupstwa gnieźnieńskiego, biskupstwa poznańskiego, 